\title{
Meeting in print
}

\section{Conference proceedings - symposia - are generally disliked, yet make up a large part of the lists of most scientific publishers. Anthony Watkinson examines this aspect of publishing.}

PUBLISHERS have their curious in-house technical terms, perhaps to bemuse authors, and when they write about symposia they mean conference proceedings and not, as was once the case, any variety of multi-authored book. To put it mildly this type of publication has a bad name. Symposia are a major vehicle of scientific communication, but with one or two notable exceptions, such as the series emanating from Cold Spring Harbor Laboratories, they are generally condemned and disliked. So why do publishers find them so attractive?

Commissioning editors are familiar with the fact that when they seek advice from an academic about publishing a symposium the adviser often seems to be writing in reply as if quoting from a partially remembered script. Unreserved condemnation is frequent:

There are far too many symposia published. Like the others, we are likely to get from this one a book which will be out of date before it is published and which will be both uneven in level and patchy in quality. It should be rejected.

Where there is approval it is grudging:

Although I am against such publications as a matter of principle, I am prepared to make an exception in this case where there is a real need for a state-of-the-art volume in this very important (to be interpreted - my own) field. It is rapidly growing (my research group managed to get out five papers last year) and is attracting a lot of interest. I must also say that the organizer has managed to get together the leading people (including me but that does not influence my judgement) and on balance I am inclined to recommend that you take this one on.

These are generalizations, seen through the distorting glass of publishing preoccupations. The designation "symposia" actually covers a wide range of types of books and some demarcation within the genre is necessary. A convenient criterion is the nature of the (type) setting. Does the book represent the summit of the printer's art - what used to be letterpress and art paper - or crummy old author-prepared camera-ready copy?

The heavy end of the range is best represented by those old-established series produced for British learned societies, characteristically in classical biology. A very high standard of production is expected. Line figures are even redrawn and relettered to achieve conformity - the ultimate in luxury now that the drafting staffs of publishers have been cut to the bone - and much care is lavished on micrographs of sections of voles' testicles and suchlike. Usually pressure to get the book out quickly is not overwhelming, and in general it is as a collection of authoritative reviews that such symposia are judged.

Whereas such series are often cited as serials (symposia of this society and proceedings of that), there are other lypeset review volumes which are presented as if

Even where the book is admitted to be a symposium the words "based on" or "derived from" coyly suggest something else.

the origin of the book were a shameful secret to be relegated to the preface. Even where the book is admitted to be a symposium the useful words "based on" or "derived from" coyly suggest something else; and it is quite common to choose a more challenging and supposedly "selling" title (The Worm in the Bud) when the subtitle reveals that we are concerned with the third international meeting of the society for weevil watchers.

It is not uncommon for the multivolumed proceedings of the big disciplinary meetings (for example the international get-togethers of immunologists) to be "properly" typeset, after having been seriously edited, while at the same time coming out within six months of the actual meeting. In older disciplines both the product of such proceedings and the function of the meeting of the international union itself are less highly regarded. To manage the schedule prodigious organizational capacity is required both of the publications committee of the learned body and the publisher; a team of desk-editors, who usually have their being in windowless rooms, may be plucked from their desks and flown to Kyoto by an apparently generous employer, there to spend their days and nights copy-editing.

Another category of typeset symposia is the "workshop" publication favoured by the drug houses and financed by them. These are prestige jobs and they must look like "real" books. The size of the print run and the amount of money on offer can stimulate even the most sluggish of book publishers to manage the sort of schedules which are normally possible only for journals.

Most symposia don't look like "real" books but are produced from cameraready copy. Until recently crc meant typewriter-produced script with ragged (unjustified) right-hand margins. Quite a few publishers will only "do" meetings if the editor/organizer agrees to this route. It is one of those house rules which indicate that the management has got so far away from line responsibilities that they have to rely on arbitrary criteria. It exists because those in charge want to avoid investment in composition, not because they have any wish to insist on old-style typescript as such. If the volume is to be "re-typed" after editing under the auspices of the editor/organizer, or through the institute or society concerned, the product can now look like, and indeed is, cheap printing sensu stricto. Laser printers have become commonplace in the publication units of the wealthier institutes, such as those that house the "big" physicists, and even mere universities aspire to them. Even where the machine being operated is still actually called a typewriter, the typescript can be right-hand justified and elaborately set up, by the manipulation of golf balls, in italic or bold as appropriate (or sometimes not). It does not matter that researchers in applied psychology have convincingly shown that unjustified typescript is easier to read than its badly justified equivalent. Publishers know what looks right.

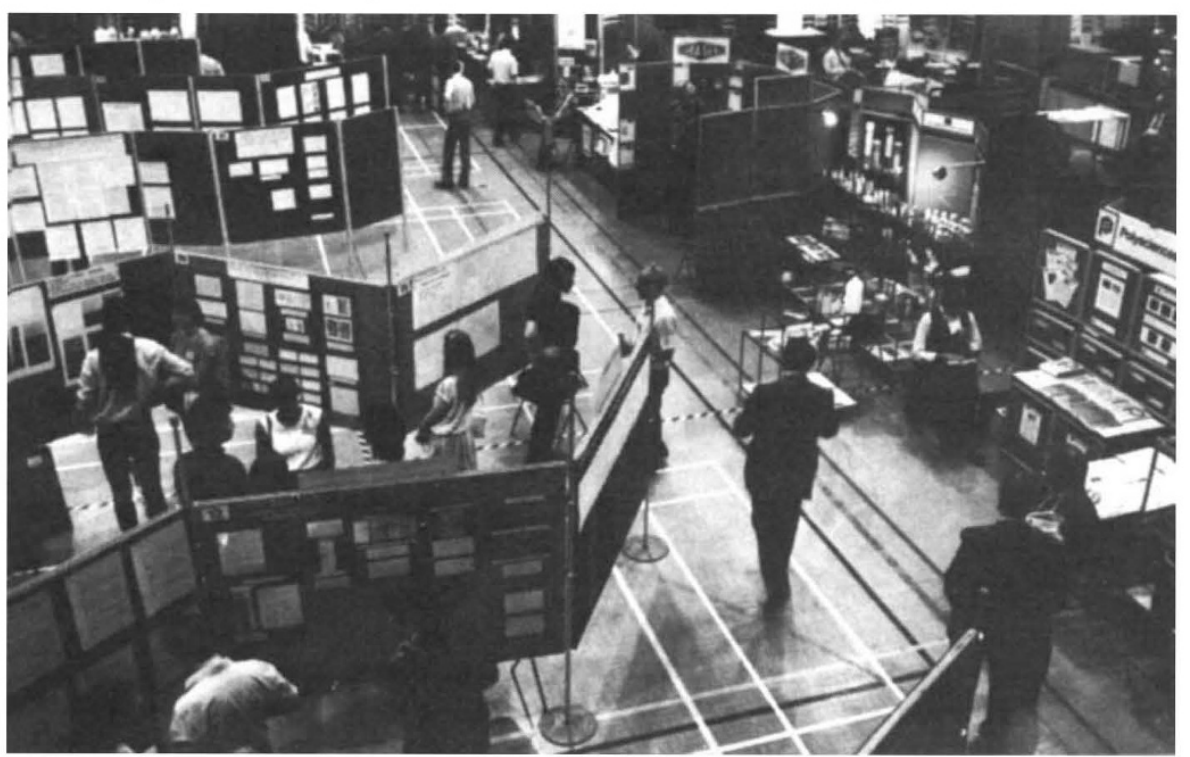

Talk among the posters. What will result from the talk inside the conference hall? 
Finally at the bottom end, as it were, are those numerous symposia produced from author-generated camera-ready copy. These are the norm, the least regarded, the most dismissed: more on them later.

Publishers don't boast about the symposia on their list. A standard publishing house in science, technology and medicine (STM) will have at least $25 \%$ of its annual output of new titles in this category, but such books will be the least promoted. In some disciplines, however, for example the neurosciences, a new publisher can build up a front-running list on little more than well-chosen proceedings and for the new branch of an existing international firm it could be argued that symposia publishing is the quickest and easiest way of getting in on the act. Many journal publishers claim to publish symposia to keep their journal editors happy. Other publishers could as reasonably claim, but don't, that the efficient publication of a meeting for a key person can put them in the running when a journal is hatched.

Publishers don't always themselves recognize that they make money out of symposia, but they do. The economics of the quick and dirty end of the spectrum

Publishers don't always recognize that they make money out of symposia, but they do.

illustrate this fact most clearly. In the first place, if there are no composition costs investment is minimized. It is hardly a major outlay to supply the familiar bluelined paper (the grid) and the subtly differing IMPORTANT INSTRUCTIONS FOR YOUR TYPIST (the rest of the package). Secondly it is often the case that this material is sent out by the academic editor himself or herself and it may also be the editor's job to make sure that the contributors sign the minimalist contract to establish that the publisher really does hold the rights. Whatever the hassles that will arise, they are for the editor to sort out, not the publisher.

The third advantage is the convention over royalties. Whereas $15 \%$ of net receipts or thereabouts is regarded as reasonable in the case of a monograph, and the sum of royalties and fees for those involved in a specially commissioned multi-authored book is much of a muchness, editors of symposia cannot hope to be propositioned with inducements like this. Ten per cent of income is tops in most cases, going to the editor/organizer only, and generally it is considered perfectly appropriate (given a buyer's market) to screw down symposium royalties to purely token levels where for other categories of book such an action would be regarded as at best unsuitable and possibly even counter-productive. All this is good for the business arithmetic. It must however be said in qualification that where major international and prestigious national learned societies are concerned, contracts involving royalty arrangements running to as much as $13 \%$ of the list price are known to exist and experienced treasurers (biochemists are good at this) have secured rather large down-payments.

Fourthly there is a further financial consideration which endears symposia to the hearts of publishing accountants. It is one area in which their fantasies can have free rein because it is generally agreed that symposia are not price-sensitive items. In theory publishers price to a market; textbooks, for example, cannot be higher than a price determined by that of the competition. In practice, although types of book mainly bought by libraries may be priced in accordance with arcane formulae that do not relate to costs - bringing into play such concepts as price ceilings (if the book is over $\$ 100$, will it go to the library commitee?) - publishing editors fight the rules to keep down the price of their own creation and someone else's life's work as a scholar. No one cares about symposia, especially the camera-ready variety. From some houses amazingly high prices - when costs are considered - and absurdly low breakevens are par for the course. Production costs may be covered if only 100 are purchased. An examination of many STM catalogues to compare the price per page of a typeset monograph and a symposium volume in the same field that has been produced from author-generated camera-ready copy may show little difference between the two categories.

Other advantageous arrangements are possible. Publishers may lash out with cash on advances and composition where the big meetings are concerned, but though they may talk of generous donations there is method in their madness. The publication is a very visible one. Spin-off books and even journals may result. And in the short term there is a good chance that the price of the book-of-the-meeting may be built into the registration fee so that costs are covered before publication. Even where the publisher is only permitted to make a special offer to participants for these sort of meetings, usually in a newish and stillcohesive field, experience shows that most of those attending do actually order the book or books at the special price and those that could not actually make it to the occasion feel that they should have the book on their laboratory shelf.

Publication for the pharmaceutical industry is a specialist area, shrouded in mystery and not to be touched on lightly; exposure of the secrets is probably punishable under Swiss Law. The subsidizing of such publications, though significant to the publishing house, represents a very small part of the marketing budget of a big drug company. The marketing manager of such an organization has simple needs; he wants a book that comes out on time, under a good imprint, and looks like a book. The publisher quotes a fee which is estimated on costs per page (plus, plus, plus) and, if his print buying is good, profitability is ensured before a copy is sold.

Actually, the most prestigious category of symposium volume is just about the least profitable category of book that the scientific publisher can take on (except for the dreaded Festschrift). The books are expensive to produce but the officers of the learned society prevent "realistic" pricing. Profits are difficult to achieve and payback is slow. If the topic of the meeting looks

...if the organism concerned is small and has lots of legs the bottom line is pretty sure to look bad.

boring to the layperson it probably is for most scientists also. It would be invidious to pick out particular topics which chill the hearts of publishers, but if the organism concerned is small and has lots of legs the bottom line is pretty sure to look bad. The author who wonders how the publisher can afford to embrace the series of the -ology Association when his own important opus has been rejected as uncommercial should turn to the journals section of the same catalogue. It is a matter of sprats and mackerels.

A publisher writing in Nature must take it that publishers are in the symposium business for the cash, the contacts or both. What of the scientists' point of view? The transformation of a transient three or four days of academic exchange into an enduring collection of reviews, or a published state-of-the-art forum, can be an invaluable contribution to learning. And where a subject is emerging as a discrete area of research activity, where results are coming thick and fast or theories are presented and overturned month by month, meetings are crucial to the scientific community and their record in printed form is equally essential. In such circumstances, where something more discursive and less restricted than the scientific paper is required, and some sort of synthesis, albeit tentative, must be attempted, symposium proceedings are the most useful and probably the only practicable form of written communication.

There are other occasions where symposia are to welcomed but not always. In the past there was always some publisher at hand to take on any meeting however unappetizing it might be. It is said now that some proffered volumes are rejected by all. One might hope too that more organizers will look to the Harden and Gordon model and not seek volume publication as a reflex action, and that more contributors who have given their all several times already will refuse to submit a paper when another unexpected demand for the same material is made. And if publication is accepted to be a good idea by everyone concerned, perhaps publishers may consider treating symposia less as the cannon fodder of the book industry but rather as books with a purpose to be cherished and made the best of.

Anthony Watkinson is a Commissioning Editor at Oxford University Press. 